\title{
Human milk banking at Sorrento Maternity Hospital, Birmingham
}

\author{
S E Balmer, B A Wharton
}

Milk banking refers to the collection, processing, and storage of human milk and feeding that milk to someone other than the donor's own baby. In some ways it is a more simplified and less controlled form of wet nursing. Similarly it has had periods of favour and times when it was unpopular, as happened to wet nursing in the 15 th century because of the spread of syphilis. ${ }^{1}$ Currently milk banking is going through a phase of uncertainty. One of the reasons is that babies have become infected with the HIV while breast feeding. ${ }^{2-5}$ The virus has also been found in cell free breast milk. ${ }^{6}$ The second reason is that there are now commercially available formulas designed especially for the low birthweight infant. These formulas provide enough energy and other nutrients to meet the expected growth of a preterm baby had it still been 'in utero' (with a few exceptions such as calcium). Recent studies comparing banked breast milk with a low birthweight formula confirm this difference in growth, ${ }^{7}$ and perhaps more importantly have shown that the developmental quotient at 9 months was 0.25 standard deviations lower in those receiving donor milk. ${ }^{8}$

For these and possibly other reasons there are many fewer milk banks than previously. In 1981 the Department of Health and Social Security (DHSS) listed 19 'established milk banks in Great Britain'. 9 To our knowledge only six are now functioning.

\section{History}

The first milk bank was set up in Vienna in 1900 and 10 years later another was organised in Boston, USA. The first milk bank in the UK was opened at Queen Charlotte's London. After the second world war milk banks designed to supply a service to other hospitals were set up, notably the Sorrento Maternity Hospital in Birmingham, St Davids at Cardiff, Bristol, and later Leicester and Liverpool. In 1973 there were five large 'commercial' milk banks in Britain at Queen Charlotte's in London, St David's in Cardiff, Sorrento in Birmingham, Southmead in Bristol, and Royal Alexandra in Brighton. Now only the Sorrento Maternity Hospital regularly supplies milk to other hospitals.

The human milk bank in Birmingham was established in 1950 at Birmingham Children's Hospital and transferred to Sorrento Maternity Hospital in $1955 .^{10}$ In 40 years it has had over
10000 donors and collected and distributed approximately 50000 litres of breast milk; currently it processes about 700 litres per year. It supplies milk to the neonatal unit at Sorrento Maternity Hospital, other hospitals in the West Midlands, and elsewhere outside the region.

The use of donor breast milk

There are many well known theoretical immunological advantages to breast feeding, particularly the anti-infective properties and reduction in allergic reactions. ${ }^{11-12}$ Work from Dundee has shown a reduction in gastrointestinal illness and admission to hospital in those breast fed for at least 13 weeks. ${ }^{13}$ Also the large multicentre trial based in East Anglia found that preterm babies fed infant formulas were 6-10 times more likely to develop necrotising enterocolitis than those fed breast milk and pasteurised donor milk seemed to be as protective as maternal milk. ${ }^{14} \mathrm{~A}$ feeding study in India has shown that pasteurised breast milk still confers protection from infection. ${ }^{15}$

It is often thought that banked breast milk has considerably reduced immunological factors because of the heating it undergoes during pasteurisation. Studies have shown that the time and temperature of pasteurisation is important in determining the content of lactoferrin, lysozyme, and immunoglobulin in pasteurised milk. Holder pasteurisation is for 30 minutes at $63^{\circ} \mathrm{C}$ (designed to kill Mycobacterium tuberculosis) but breast milk is mostly contaminated with skin commensals which are more susceptible to lower temperatures. Table 1 shows that a reduction of temperature to $56^{\circ}$ improves the content of protective factors. ${ }^{16-20}$

Therefore despite the disadvantages of slower overall growth and development with prolonged use there are a number of inherent advantages in the use of expressed breast milk in the short term for the ill newborn baby. The custom here and in many other units has been to use banked breast milk only in the very low birthweight baby and then only during the first week or so while achieving gastrointestinal tolerance. Thereafter as the accent of care changes from 'survival' to 'rehabilitation and catch up growth', a normal or low birthweight infant formula is gradually substituted. One other feature of the large East Anglian studies was the better gastrointestinal tolerance of banked breast milk compared with a low birthweight formula during 
Table 1 Reduction of immunological factors in breast milk after pasteurisation at two temperatures in different centres (reduction as \% of level in untreated milk)

\begin{tabular}{llllll}
\hline & $63^{\circ}$ for $30 \mathrm{~min}$ & & $56^{\circ}$ for $30 \mathrm{~min}$ \\
\cline { 2 - 5 } \cline { 5 - 6 } & Reading $^{16}$ & Oxford $^{17}$ & Cardiff $^{18}$ & ${\text { Stamford, } \text { USA }^{19}}$ & Oxford $^{20}$ \\
\hline Lactoferrin & 65 & NT & 57 & NT & 10 \\
Lysozyme & Nil & 36 & 24 & NT & Nil \\
IgA & 22 & 21 & Nil & 33 & 10 \\
\hline
\end{tabular}

NT $=$ not tested mothers are bled in their own homes to save them any inconvenience. Often milk is donated before we know the results of the HIV antibody test and this milk is stored in a separate freezer until the result is known.

The Association of British Insurers have provided us with a leaflet explaining that mothers applying for life insurance will not be affected by having had an HIV antibody test as part of our donor screening programme. Mothers who are expressing milk for their own babies on the neonatal unit are not tested for HIV antibodies. However if they have a surplus in excess of the requirements of their own baby which could be used for another baby, that mother is also tested. of colleagues use banked breast milk as the first enteral feed after neonatal bowel surgery.

Apart from its use with the ill newborn an occasional use is for severe gastrointestinal food intolerance. However as the affected infants are larger than newborns the volume demand is greater and has occasionally placed strains on supplies.

\section{Screening of donors}

Donor mothers are asked about their medical history with particular reference to infectious diseases. Milk is not accepted from mothers who are hepatitis B carriers or have antibodies to syphilis. Donors are asked not to give milk to the milk bank if their baby becomes ill at any time.

Donors are also questioned about any medication that they are receiving. There are very few drugs that prohibit a mother from breast feeding her own fit healthy baby but as donor milk is being fed to sick infants of other mothers, more precautions are taken. We do not accept milk from mothers (a) who are regularly receiving any drugs other than the contraceptive pill or the occasional analgesic such as aspirin or paracetamol; (b) who have received antibiotics in the previous 48 hours; and (c) who admit to smoking more than 10 cigarettes a day.

Each mother must have a refrigerator or freezer so that her milk can be stored frozen as the mothers are visited only once every 10 days.

\section{HIV antibody testing of donors}

Evidence suggests that breast milk might be involved in the transmission of HIV as breast fed babies of recently infected. mothers have developed AIDS. ${ }^{2-5}$

In accordance with the directive from the DHSS all donors at Sorrento Maternity Hospital are now screened for HIV antibodies. ${ }^{22}$ The necessity for a blood test is explained to every mother when she first contacts the milk bank about donating milk. Only four mothers (out of 470) have refused to be tested. When the milk bank nurse visits the mother for the first time they are given a form (similar to that given to blood donors) which lists the high risk groups for AIDS and asks them not to offer their milk if they could fall into any category. Each mother gives written consent to be tested for HIV antibodies. Should a donor be HIV positive, arrangements for counselling are made. All

\section{Collection of breast milk}

Donor mothers are provided with a hand breast pump not a breast reliever (a bicycle horn pump). Careful instructions on how to clean and sterilise the pump are provided in a small booklet. Breast relievers are not suitable for collecting banked breast milk because they are difficult to clean and sterilise. The hand pump used is made by Egnell Ameda (Taunton), costs approximately $£ 10$, and most mothers find it satisfactory. Hand expression is the cleanest method of expressing milk but most mothers prefer to use a hand pump. If a mother is expressing milk for her own baby on the neonatal unit she is supplied with an electric pump (Egnell Ameda, Humolactor). This makes it easier to sustain lactation as to some extent it mimicks the stimulation of normal suckling.

Mothers are also supplied with a shell to collect 'drip' milk which leaks from the opposite breast to the one being suckled. Mothers are advised only to collect drip milk while feeding and not at any other time, so that the milk supply is not increased by the pressure of the shell on the breast for too long a period. Drip milk is foremilk with a lower fat content and thus lower energy content than expressed or hind milk. We therefore encourage the collection of expressed milk, but do not exclude any drip milk. Milk is transferred from the breast pump to Axicare breast milk bottles (Colgate Axicare, Windsor; 120 or $240 \mathrm{ml}$ size). The bottles are reused and are not sterile. In between use all bottles are thorougly cleaned in a washing machine and dried, which we have found adequately disinfects them.

All milk is stored in the donor's freezer at $-20^{\circ} \mathrm{C}$ or in the freezer part of her refrigerator at $-5^{\circ} \mathrm{C}$ until it is collected by the milk bank staff. Mothers are visited at home by the milk bank nurses every 10 days to collect the frozen milk and deliver a fresh supply of bottles. While on the 'milk round' the nurses put all bottles of frozen milk into a cooler box to ensure that the milk remains frozen on its journey back to the milk bank

\section{Microbiological quality control}

Each bottle of milk supplied by the mothers is examined bacteriologically. The day before the 
milk is pasteurised it is thawed at room temperature for three hours and $10 \mu \mathrm{l}$ milk (using a standard loop) is inoculated on to CLED agar (cystine-lactose-electrolyte deficient, CM423 Oxoid) and incubated at $37^{\circ} \mathrm{C}$ overnight. The milk is kept at $4^{\circ} \mathrm{C}$ overnight.

There are no accepted microbiological criteria for the control of donor milk. The DHSS report The Collection and Storage of Human Milk described methods but left criteria 'to the microbiologist concerned with the setting up of each individual milk bank'. 9 The microbiological criteria used at the Sorrento Maternity Hospital for accepting milk for pasteurisation are:

(1) Milk with counts of less than $10^{3}$ colony forming units $(\mathrm{cfu}) / \mathrm{ml}$ is used regardless of the organisms present.

(2) Milk with counts of more than $10^{5} \mathrm{cfu} / \mathrm{ml}$ is not used.

(3) If milk has counts between $10^{3-5} \mathrm{cfu} / \mathrm{ml}$ it is only used if the organisms are skin commensals-for example, Staphylococcus epidermidis, viridans streptococci, and diphtheroids. Milk is not used if it has counts of more than $10^{3} \mathrm{cfu} / \mathrm{ml}$ of Staphylococcus aureus, any Gram negative rod (lactose fermenting and Pseudomonas sp), $\beta$ haemolytic streptococci or Streptococcus faecalis. These criteria are similar to those recommended by the milk bank at King's College Hospital, London. ${ }^{23} 24$

These criteria are necessary because pasteurisation is ineffective if milk is heavily contaminated with micro-organisms. A linear relationship exists between the logarithm of the number of surviving organisms at a given temperature and the length of time for which the organisms are exposed to that temperature. Although heat treatment will kill most bacteria present in milk, the toxins produced by some bacteria are not necessarily destroyed by heat. It is therefore advisable to eliminate milk con-

Table 2 Microbiological analysis of 5872 bottles of milk collected during one year

\begin{tabular}{lc}
\hline & No $(\%)$ of bottles \\
\hline Total counts of organisms (cfu/ml) & $1934(33 \cdot 0)$ \\
$<10^{3}$ & $333(5 \cdot 7)$ \\
$10^{3}$ & $2376(40 \cdot 5)$ \\
$10^{4}$ & $990(16 \cdot 9)$ \\
$10^{5}$ & $239(4 \cdot 1)^{*}$ \\
$>10^{5}$ & \\
Organisms present & \\
$S$ epidermidis & $2809(47 \cdot 8)$ \\
$S$ aureus & $232(3 \cdot 9)$ \\
Coliforms & $688(11 \cdot 7)$ \\
Enterococci & $22(0 \cdot 4)$ \\
\hline
\end{tabular}

*This milk is rejected, milk with counts of $10^{3-5}$ may be rejected depending upon the organisms found-see text.

Table 3 Chemical analysis of breast milk (per $100 \mathrm{ml}$ )

\begin{tabular}{|c|c|c|c|}
\hline & \multicolumn{2}{|c|}{$\begin{array}{l}\text { Donor milk from } 75 \text { batches, each batch } \\
\text { containing milk from } 5-20 \text { donors }\end{array}$} & \multirow{2}{*}{$\begin{array}{l}\text { Mature } \\
\text { human } \\
\text { milk } \\
(D H S S)^{28}\end{array}$} \\
\hline & Mean $(S D)$ & Range & \\
\hline $\begin{array}{l}\text { Sodium (mg) } \\
\text { Fat (g) } \\
\text { Protein (g) } \\
\text { Lactose (g) }\end{array}$ & $\begin{array}{rr}17 \cdot 0 & (3 \cdot 9) \\
2 \cdot 2 & (0 \cdot 3) \\
1 \cdot 2 & (0 \cdot 1) \\
7 \cdot 2 & (0 \cdot 2)\end{array}$ & $\begin{array}{r}11 \cdot 0-34 \cdot 0 \\
1 \cdot 6-3 \cdot 4 \\
1 \cdot 0-1 \cdot 4 \\
6 \cdot 8-8 \cdot 8\end{array}$ & $\begin{array}{r}15 \cdot 0 \\
4 \cdot 2 \\
1 \cdot 3 \\
7 \cdot 0\end{array}$ \\
\hline Calculated energy $(\mathrm{kJ})$ & 217 & & 293 \\
\hline
\end{tabular}

taminated with any toxin producing organisms such as Escherichia coli and $S$ aureus. Theoretically lipases, proteases, and decarboxylases that are released by certain micro-organisms such as Gram negative bacilli, faecal streptococci, and $S$ aureus during pasteurisation could cause undesirable effects in the newborn. ${ }^{25}$

All acceptable milk is strained through sterile muslin to remove any hairs or bits of fluff from donor's clothes. The donor milk is then pooled. Only milk expressed by a mother for her own baby in the neonatal unit is kept separately. Pooled milk is transferred to $250 \mathrm{ml}$ glass Winchester bottles for pasteurising.

A further check of the bacterial content of the raw pooled milk is then made by inoculating another $10 \mu \mathrm{l}$ loop on to CLED agar. This check ascertains that milk has not become contaminated with unacceptable organisms (see above) during straining and pooling. If milk had become contaminated the whole batch would be discarded.

\section{Contamination of milk}

About $10 \%$ of bottles of milk supplied by mothers are discarded as being too contaminated for use. The detailed microbiological analysis for milk collected during one year is summarised in table 2 . Milk with very high counts of bacteria is usually contaminated with coliforms and often there is more than one type of bacterium present in each bottle of milk.

\section{Pasteurisation}

All milk is pasteurised at $56^{\circ} \mathrm{C}$ for 30 minutes in a custom built pasteuriser (Scott Weston) and rapidly cooled to $10^{\circ} \mathrm{C}$ at the end of the cycle. The model we use is no longer commercially available but is very similar to the Colgate Axicare CM80. The whole cycle (time and temperature) is recorded on a chart that is kept for reference.

All milk should be at room temperature immediately before pasteurising because pasteurising is not effective if the temperature has to be raised considerably during the cycle. ${ }^{26}$

Most skin bacteria are killed and viruses including HIV are inactivated at $56^{\circ} \mathrm{C}$ for 30 minutes. ${ }^{27}$ The efficacy of pasteurisation is checked by including a test bottle in each batch. The test bottle is a $250 \mathrm{ml}$ Winchester containing water in which a small bottle containing 5 $\mathrm{ml}$ of raw milk is submerged. After pasteurisation $0.2 \mathrm{ml}$ milk from that sample is inoculated on to two blood agar plates, one is incubated aerobically and the other anaerobically at $37^{\circ} \mathrm{C}$ for 48 hours. ${ }^{9}$ A batch of milk is not used until a report of no growth for this sample is received from the laboratory.

After pasteurisation all milk is stored frozen until use when it is defrosted either in a refrigerator or at room temperature. Pasteurised breast milk can be stored frozen for up to six months. Each batch is numbered and it is recorded which batch is fed to each baby or sent to other hospitals in accordance with DHSS recommendations. ${ }^{22}$ 


\section{Chemical analysis}

Each batch of pasteurised milk is analysed for its chemical composition, free of charge by Farley Health Products. A $70 \mathrm{ml}$ sample with bronopol milk preservative (2-bromo-2-nitropropan-1, 3-diol) added to it is sent through the post. The contents of protein, fat, lactose, and sodium are shown on the label of each bottle of milk that leaves the milk bank. The values obtained during one year are shown in table 3.

\section{Storage and despatch}

Sorrento Maternity Hospital supplies milk to other hospitals in the Birmingham area on a regular basis. If hospitals further afield require milk, each bottle is wrapped in bubble polythene, packed in cardboard boxes and despatched via the Red Star parcel service or British Rail.

\section{Funding}

The Sorrento milk bank is run in conjunction with the milk kitchen for the neonatal unit and is funded by the South Birmingham Health Authority. The staff for both the milk kitchen and milk bank include a microbiologist, part time sister, two part time nursery nurses, a nursing auxillary, and a domestic assistant. The milk bank has its own vehicle to enable the staff to visit the mothers in their homes. All milk is sold at currently $£ 15$ per litre either back to South Birmingham Health Authority or to any other authority requiring the milk.

\section{Conclusion}

A number of milk banks closed after the DHSS advised screening every donor for HIV ${ }^{22}$ because it was felt mothers would not find it acceptable. There were also doubts about the suitability of donor milk for preterm babies. We have shown that mothers are cooperative in being screened for HIV, and it has not created the problems that we had anticipated. There are still arguments for feeding the sick preterm newborn baby with breast milk during the first weeks or so of life. In our opinion therefore milk banking should be continued. We do consider that some degree of both microbiological and chemical monitoring is necessary and the methods used in the Sorrento milk bank have been described.
1 Fildes V. Wet nursing: a history from antiquity to the present. Oxford: Blackmore, 1988

2 Ziegler JB, Cooper DA, Johnson RD, Gold J. Postnata transmission of AIDS associated retrovirus from mother to infant. Lancet 1985; i:896-7.

3 Lepage P, Van de Perre P, Caraël $\mathrm{M}$, et al. Postnatal transmission of HIV from mother to child. Lancet 1987; it 400.

4 Weinbrek P, Loustaud V, Denis F, Vidal B, Mounier M, De Lumley L. Postnatal transmission of HIV infection. Lancet 1988;i:482.

5 Van de Perre P, Simonon A, Msellati P, et al. Postnatal transmission of human immunodeficiency virus type from mother to infant. $N$ Engl f Med 1991;325:593-8.

6 Thiry L, Sprecher-Goldberg S, Jonckneer T, et al. Isolation of AIDS virus from cell free breast milk of three healthy virus carriers. Lancet 1985; ii:891-2.

7 Lucas A, Gore SM, Cole TJ, et al. Multicentre trial on feeding low birth weight infants: effects of diet on early growth. Arch Dis Child 1984;59:722-30.

8 Lucas A, Morley R, Cole TJ, et al. Early diet in preterm babies and developmental status in infancy. Arch Dis Child $1989 ; 64: 1570-8$.

9 Department of Health and Social Security. The collection and storage of human milk. London: HMSO. 1981. (Report on storage of human milk. London: Hacial subjects. No 22 .)

10 Wharton BA. Immunological implications of alternatives to mother's milk. II Donor milk. In: Wilkinson AW, ed. The immunology of infant feeding. New York: Plenum Press, 1981: 123-35.

11 Williams AF, Fisher C, Greasley V, Trayler H, Woolridge MW, Baum JD. Human milk banking. $\mathcal{f}$ Trop Pediatr 1985;31:185-90.

12 Lucas A, Brooke OG, Morley R, Cole TJ, Bamford MF. Early diet of preterm infants and development of allergic and atopic disease: randomised prospective study. $B M F$ 1990;300:837-40.

13 Howie PW, Stewart Forsyth J, Ogston SA, Clark A, Florey C du V. Protective effect of breast feeding against infection. BMF 1990;300:11-5.

14 Lucas A, Cole TJ. Breast milk and neonatal necrotising enterocolitis. Lancet 1990;336:1519-23.

15 Narayanan I, Prakesh K, Murthy NS, Gujral VV. Randomised controlled trial of the effect of raw and Holder pasteurised human milk and formula supplements on the incidence of neonatal infection. Lancet 1984;ii:1111-3.

16 Ford JE, Law BA, Marshall VME, Reiter B. Influence of the heat treatment of human milk on some of its protective heat treatment of human milk on som.

17 Gibbs JH, Fisher C, Bhattacharya S, Goddard P, Baum JD. Drip breast milk: its composition, collection and pasteurisation. Early $\cdot$ Hum Dev 1977;1:227-45.

18 Evans TJ, Ryley HC, Neale LM, Dodge JA, Lewarne UM. Effect of storage and heat on antimicrobial proteins in human milk. Arch Dis Child 1978;53:239-41.

19 Liebhaber M, Lewiston NJ, Asquith MT, Aldo-Arroyo L, Sunshine P. Alterations of lymphocytes and of antibody content of human milk after processing. $\mathcal{F}$ Pediatr 1977;91: 897-900.

20 Wills ME, Han VEM, Harris DA, Baum JD. Short time low temperature pasteurisation of human milk. Early Hum Dev 1982;7:71-80.

21 Lucas A. AIDS and human milk bank closures. Lancet 1987; i:1092-3.

22 Department of Health and Social Security. HIV infection, breastfeeding and human milk banking. London: HMSO, 1988. (PL/CMO(88)13 and PL/CMO(88)7, 27 April 1988.)

23 Williamson S, Hewitt JH, Finucane E, Gamsu HR. Organisationson $\mathrm{S}$, Hewitt JH, Finucane $E$, Gamsu neonatal intensive care. $B M \mathcal{F} 1978 ; \mathrm{i}: 393-6$.

24 Williamson S, Finucane E, Gamsu HR, Hewitt JH. Staphylococcus aureus in raw human milk for neonates. $B M \mathcal{F}$ 1978;i:1146.

25 De Louvois J. Laboratory monitoring of banked human milk. Med Lab Sci 1982;39:311-8.

26 Scott GM, Kelsey MC. Assessment of the Axicare human milk pasteuriser (CM80). $\mathcal{J}$ Hosp Infect 1989;14:163-8

27 Eglin RP, Wilkinson AR. HIV infection and pasteurisation of breast milk. Lancet 1987; 1093.

28 Department of Health and Social Security. The composition of mature human milk. London: HMSO, 1977. (Report on health and social subjects. No 12.) 